\title{
Kolaborasi Digital Signage dan Chatbot Messenger Sebagai Layanan Penyedia Informasi Akademik
}

\author{
Rio Jumardi ${ }^{1, *}$, Lia Farokhah ${ }^{2}$, Maghfirah ${ }^{1}$ \\ ${ }^{1}$ Program Studi Teknik Informatika, Sekolah Tinggi Teknologi Bontang, Bontang, Indonesia \\ ${ }^{2}$ Program Studi Informatika, STIMIK Asia, Malang, Indonesia \\ Email: ${ }^{1}$ riojumardi@stitek.ac.id, ${ }^{2}$ farokhah@asia.ac.id, ${ }^{3}$ maghfirah@ @ stitek.ac.id \\ Email Penulis Korespondensi: riojumardi@stitek.ac.id
}

\begin{abstract}
Abstrak-Saat ini penyebaran informasi semakin mudah diperoleh dan tersebar dalam berbagai bentuk cetak maupun elektronik, namun terkadang masih disajikan dengan kualitas yang buruk. Tingginya kualitas informasi menjadikan informasi bertransformasi menjadi pengetahuan yang menjadi dasar dalam pengambilan keputusan serta menjadi sumber daya tersendiri untuk instansi atau organisasi. Pemanfaatan teknologi dalam berbagi pengetahuan sebuah organisasi diperlukan sebagai sarana peningkatan efektifitas teknologi dan proses bisnisnya. Metodologi pengembangan sistem yang digunakan pada penelitian ini menggunakan metode GRAPPLE yang merupakan kepanjangan dari Guidelines for Rapid Application Engineering dengan tahapan Requirement Gathering, Analysis, Design, Development dan Deployment. Papan digital berbasis digital atau digital signage dapat mengganti papan informasi berbahan konvensional seperti kayu atau besi dengan memberikan informasi yang akurat, relevan, tepat waktu dan bekerja secara dinamis. Chatbot messenger dapat membantu memberikan informasi akademik kepada mahasiswa secara dua arah dengan konsep request-response dari dan kepada mahasiswa melalui media telegram messenger. Kolaborasi antara digital signage dan chatbot messenger dapat membantu mahasiswa dalam pemenuhan informasi terkait akademik secara efektif dan efisien.
\end{abstract}

Kata Kunci: Akademik, Chatbot, Digital Signage, GRAPPLE, Informasi

Abstract-At present, the dissemination of information is easier to obtain and spread in various forms of print and electronic, but sometimes it is still presented with poor quality. The high quality of information makes that information be transformed into knowledge that is the basis for decision making and become a separate power source for the agency or organization. The use of technology to share knowledge an organization is necessary as a means of improving the effectiveness of the technology and business processes. System development methodology used in this research using GRAPPLE which stands for Rapid Application Guidelines for Requirements Engineering with the stage of Gathering, Analysis, Design, Development and Deployment. Digital boards based on digital or digital signage can replace information boards made from conventional materials such as wood or iron by providing accurate, relevant, timely and dynamically working information. Chatbot messenger can help provide academic information to students in two directions with the concept of request-response from and to students via telegram messenger.Collaboration between digital signage and chatbot messenger can help students in fulfilling academic related information effectively and efficiently.

Keywords: Academic, Chatbot, Digital Signage, GRAPPLE, Information

\section{PENDAHULUAN}

Salah satu sumber daya yang menjadi kebutuhan utama sebuah instansi adalah informasi[1]. Informasi merupakan sekumpulan data yang telah diolah sehingga mempunyai makna. Mempunyai makna berarti data telah diolah mempunyai bentuk yang lebih berguna bagi penerimanya[2]. Saat ini penyebaran informasi semakin mudah diperoleh dan tersebar dalam berbagai bentuk cetak maupun elektronik, namun terkadang masih disajikan dengan kualitas yang buruk[1]. Tiga pilar yang digunakan sebagai syarat kualitas sebuah informasi adalah informasi yang tepat waktu, relevan dan akurat[3]. Akurat berarti informasi terhindar dari kesalahan dan mencerminkan keadaan yang sebenarnya, tepat waktu berarti informasi harus up to date dan tidak terlambat kepada penerima informasi, relevan berarti penerima informasi mendapatkan manfaat dari informasi yang diperolehnya[4]. Tingginya kualitas informasi menjadikan informasi bertransformasi menjadi pengetahuan. Pengetahuan inilah yang akan menjadi dasar dalam pengambilan keputusan, pengetahuan juga menjadi sumber daya tersendiri untuk instansi atau organisasi. Pemanfaatan teknologi dalam berbagi pengetahuan (Sharing Knowledge) sebuah organisasi diperlukan sebagai sarana peningkatan efektifitas teknologi dan proses bisnisnya[5].

Penyampaian informasi yang berlangsung saat ini ditempat penelitian, berkaitan dengan jadwal perkuliahan, jadwal seminar hasil, jadwal pendadaran, pengumuman kemahasiswaan dan informasi akademik lainnya dilakukan menggunakan kertas yang ditempel pada papan pengumuman berbahan konvesional seperti kayu atau besi. Jika informasi yang disampaikan salah maka kertas harus dicetak ulang dan pengumuman yang telah ditempel pada papan pengumuman harus diganti sehingga kualitas informasi yang telah disampaikan menjadi tidak tepat waktu dan tidak bersifat dinamis. Selain itu pengumuman yang dilakukan menggunakan kertas juga akan memakan banyak biaya dikarenakan pengumuman yang telah ditempel bersifat satu kali pakai dengan ketentuan jika informasi tersebut telah kadaluarsa maka kertas tersebut tidak dapat digunakan kembali. Pada kasus yang lain berkaitan dengan informasi akademik seperti data dosen, informasi tugas akhir, seringkali mahasiswa menanyakan perihal yang sama secara berulang kepada petugas akademik terkait informasi tersebut, padahal informasi yang ditanyakan sudah pernah disampaikan sebelumnya. 
Papan informasi berbasis digital adalah upaya untuk mendapatkan layanan informasi akademik sebagai saluran informasi dalam penyampaian informasi akademik yang terdapat dalam database layanan informasi akademik[6]. Papan informasi berbasis digital adalah perangkat otomatis yang menyediakan praktik self-service dalam menyediakan informasi dari basisdata informasi akademik yang diharapkan menjadi solusi bagi mahasiswa mendapatkan informasi akademik terbaru sebagai upaya peningkatan daya saing mahasiswa dalam mengendalikan informasi[7].

Penyediaan informasi dalam bentuk papan informasi berbasis digital yang menyediakan informasi secara dinamis disebut dengan Digital Signage[8]. Digital signage merupakan penyampaian informasi melalui media display berupa layar digital yang berisi konten informasi berbasis multimedia baik berupa teks, video maupun gambar. Digital signage digunakan untuk menyampaikan informasi satu arah yaitu dari penyedia informasi kepada penerima informasi. Untuk mengatasi persoalan penyampaian informasi dua arah yaitu dari penyedia informasi kepada penerima informasi dan sebaliknya dapat memanfaatkan teknologi yang lain menggunakan chatbot messenger.

Chatbot merupakan sebuah sistem yang dapat memberikan respon berupa balasan pesan dari pengirim pesan. Chat berarti komunikasi dilakukan menggunakan media berbasis teks sedangkan bot berarti program yang diberi pengetahuan untuk memberikan respon kepada pengirim pesan[9]. Sehingga chatbot merupakan sebuah program yang dapat digunakan untuk melakukan komunikasi berbasis pesan teks dengan dengan penyampaian informasi dua arah dalam konsep request-response dari dan kepada pengirim pesan dengan cepat dan efisien[10]. Skema umum dalam pembuatan chatbot adalah dengan membuat pola dan respon. Pola atau pattern menggunakan konsep pattern matching sederhana yang didaftarkan pada program python, sedangkan untuk responnya menggunakan data yang ada pada MySql database.

Penelitian ini diharapkan mempermudah mahasiswa dalam mencari informasi yang dibutuhkan berkaitan dengan jadwal perkuliahan, jadwal pelaksanaan tugas akhir serta informasi akademik lainnya dan juga dapat membantu administrator akademik menyampaikan informasi secara dinamis, efektif dan efisien. Solusi yang ditawarkan dalam penelitian ini adalah dibuatnya kolaborasi teknologi antara digital signage dalam konsep mahasiswa hanya perlu melihat informasi yang disampaikan melalui media display terkait informasi akademik yang disimpan pada basisdata, serta menggunakan teknologi chatbot mesengger dimana mahasiswa hanya perlu melakukan request chat dan sistem akan membalas secara otomatis terkait informasi akademik yang dibutuhkan mahasiswa.

\section{METODE PENELITIAN}

Metode penelitian khususnya perancangan sistem adalah suatu perencanaan, penggambaran, dan pembuatan sistem dari beberapa elemen yang terpisah kedalam satu kesatuan yang utuh dan berfungsi yang menentukan bagaimana sistem direncanakan, didesain, dan dibangun sedemikian rupa[11]. Metodologi penelitian yang digunakan pada penelitian ini menggunakan metode GRAPPLE yang merupakan kepanjangan dari Guidelines for Rapid Application Engineering. Menurut Schumuller[12], Guidelines for Rapid Application Engineering (GRAPPLE) adalah sebuah pemodelan proses dalam pengembangan software yang menekankan pada aksi-aksi yang dilakukan pada sejumlah tahapan, setiap tahapan akan menghasilkan produk kerja dengan bentuk berorientasi objek serta pemodelan diagram UML.

Metode GRAPPLE merupakan bentuk sederhana dari konstruksi metode pengembangan sistem Rapid Application Development (RAD) yang memungkinkan sistem dirancang dengan cepat[12]. Metode ini bertujuan untuk menghasilkan sebuah sistem dengan cepat dalam waktu relatif singkat dengan tetap memperhatikan kualitas sistem yang dibangun[13]. Schumuller [12] mengemukakan tentang segmen atau tahapan dari metode pengembangan sistem GRAPPLE yang terdiri dari.

1. Requirement Gathering

Tahap yang dilakukan adalah mengambil informasi lengkap dari tempat penelitian. Ditahap ini mulai dilakukan analisa kebutuhan sistem berupa kebutuhan fungsional maupun non fungsional.

2. Analisys

Tahap ini mulai dilakukan proses analisa permasalahan dan solusi yang akan ditawarkan berupa arsitektur sistem.

3. Design

Tahap ini mulai dilakukan proses perancangan solusi berupa model konseptual sistem maupun database.

4. Development

Tahap ini mulai direalisasikan model konspetual pada tahap sebelumnya. Realisasi dalam bentuk tampilan antar muka, membangun code program dan proses pengujian program.

5. Deployment

Tahap dimana produk yang dihasilkan di distribusikan kepada pengguna. Pengguna yang dimaksud adalah sivitas akademika dilingkungan perguruan tinggi. 


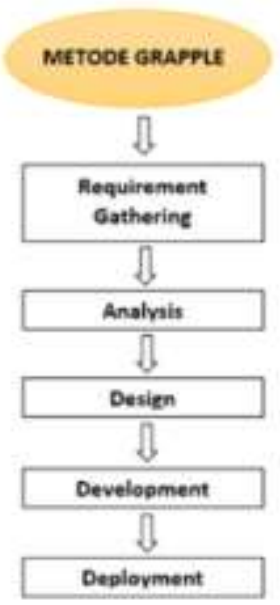

Gambar 1. Metode GRAPPLE

\section{HASIL DAN PEMBAHASAN}

Requirement Gathering, merupakan tahap pertama dalam pengembangan sistem dimana dilakukan pengumpulan kebutuhan sistem. yang akan dijadikan dasar dalam membangun sistem yang tepat.

1. Functional Requirement

a. Pada layar informasi terdapat informasi berupa jadwal perkuliahan perhari, jadwal seminar maupun pendadaran tugas akhir, informasi kampus berupa video atau gambar dan teks berjalan untuk pengumuman.

b. Terdapat status aktif atau tidak aktif untuk beberapa informasi yang akan ditampilkan pada digital signage.

c. Kata yang digunakan sebagai perintah dalam chatbot didaftarkan menggunakan bahasa python.

d. Balasan dari chatbot berdasarkan data yang ada pada Mysql database.

2. Non Functional Requirement

a. Digital signage hanya berbasis tampilan tunggal berisi informasi yang akan ditampilkan pada layar LCD gerbang kampus.

b. Chatbot yang digunakan pada penelitian ini adalah telegram mesenger.

Analysis, pada tahap ini dilakukan perancangan arsitektur sistem yang akan dibangun, fungsinya adalah untuk mengetahui lebih dalam lagi kebutuhan teknis dan hardware yang akan digunakan. Adapun arsitektur sistem dari penelitian ini dapat dilihat pada gambar 2 .

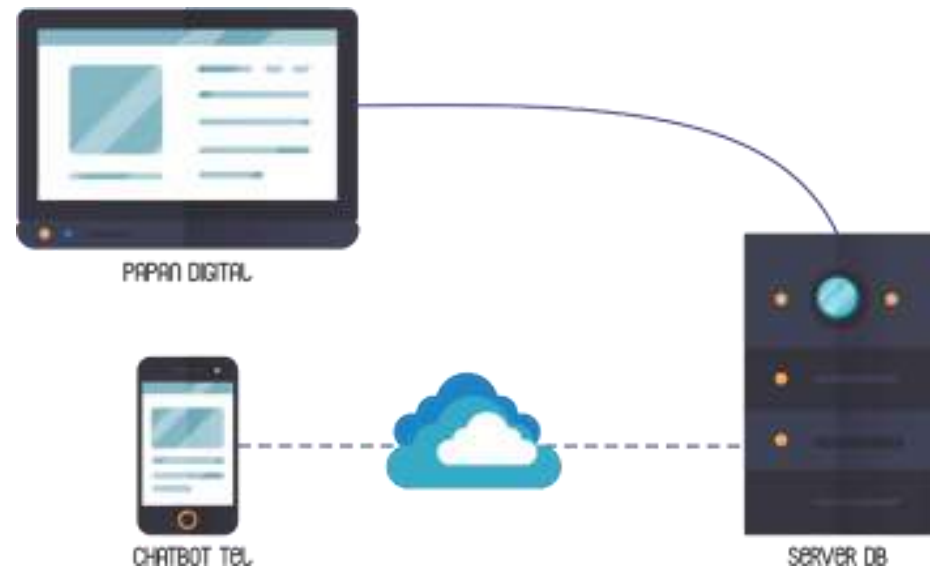

Gambar 2. Arsitektur Sistem

Design, merupakan tahap pembuatan perancangan model konseptual dari sistem yang akan dibangun. Beberapa model konseptual yang akan dibangun adalah usecase diagram. Untuk model konsepetual datanya menggunakan Relasi Antar Tabel. Perancangan cepat tampilan antar muka juga akan dilakukan pada tahap ini. Usecase diagram pada penelitian ini dapat dilihat pada Gambar 3. 


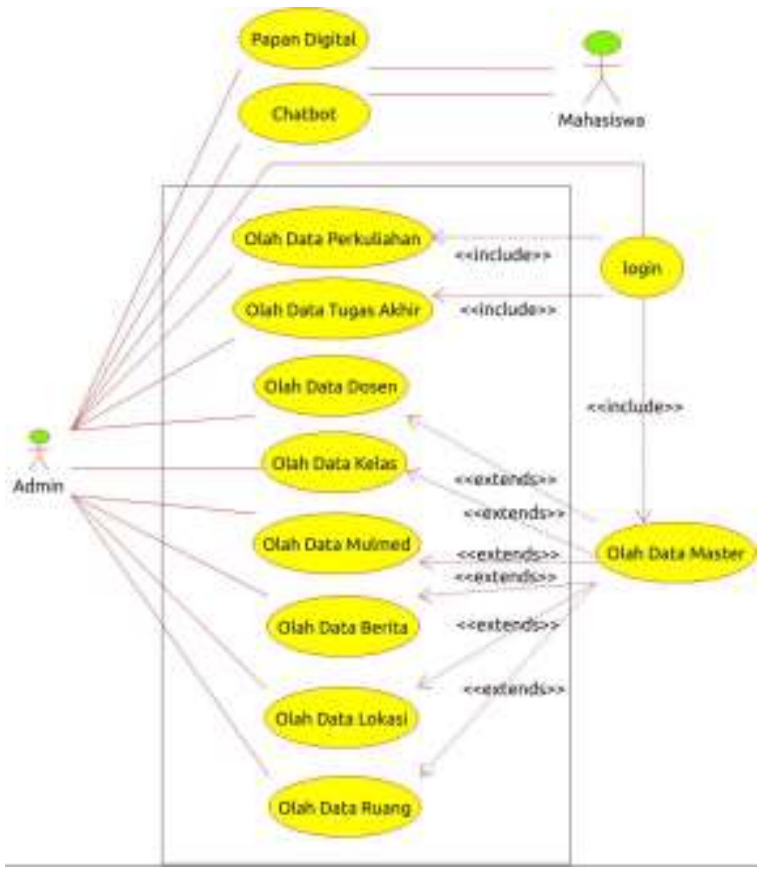

Gambar 3. Usecase Diagram

Terdapat dua aktor pada usecase diagram yaitu mahasiswa dan admin. Mahasiswa yang dapat melakukan melihat informasi pada digital signage dan melakukan request informasi pada chatbot messenger. Sedangakan admin melakukan olah data yang sesuai dengan apa yang akan ditampilkan dan diberikan kepada mahasiswa. Olah data yang dilakukan admin meliputi olah data jadwal perkuliahan, jadwal seminar dan pendadaran serta olah data master. Untuk mewujudkan aktifitas ini dapat berlangsung maka diperlukan sebuah basisdata tempat penyimpanan datanya.

Perancangan antar muka juga dilakukan pada tahap ini. Informasi yang ditampilkan pada digital signage berupa informasi jadwal perkuliahan, jadwal seminar hasil, jadwal pendadaran, logo dan alamat kampus, informasi berupa video dan atau gambar serta informasi melalui teks berjalan. Informasi yang ditampilkan pada bagian jadwal perkuliahan berupa waktu dan ruang perkuliahan, nama matakuliah dan jumlah sks serta nama dosen pengampu.

Informasi yang ditampilkan pada jadwal seminar dan pendadaran berupa hari dan waktu pelaksanaan siding, nama mahasiswa dan judul tugas akhir. Rancangan tampilan antar muka digital signage pada penelitian ini dapat dilihat pada Gambar 4.

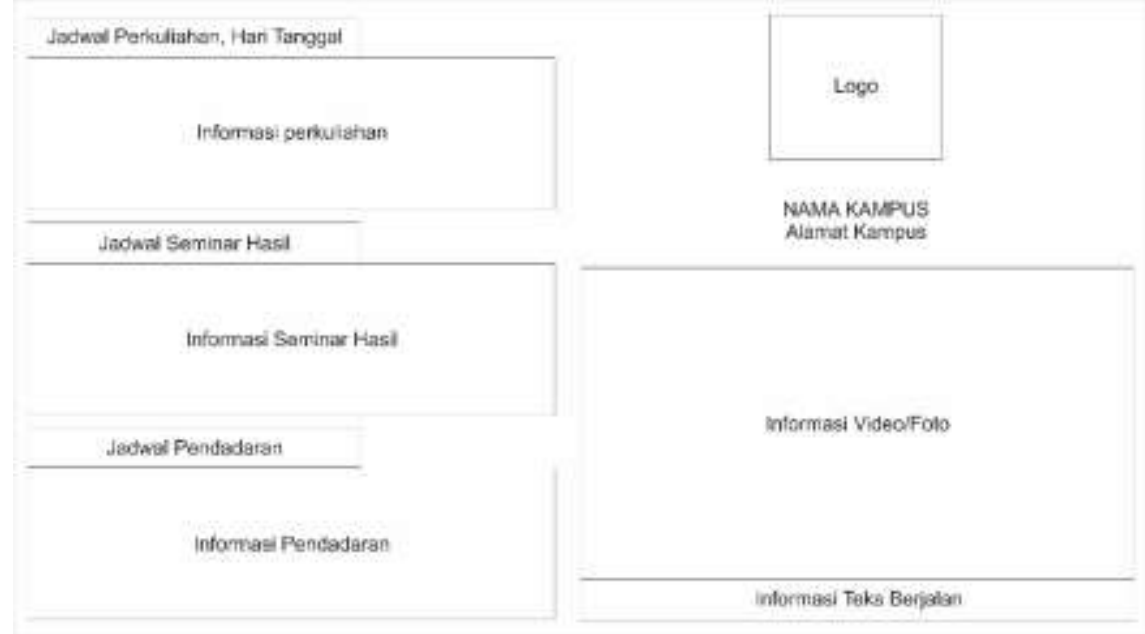

Gambar 4. Rancangan Tampilan Antar Muka Digital signage

Relasi antar tabel merupakan model konseptual yang digunakan untuk menggambarkan keterkaitan antar tabel dalam basisdata. Pada penelitian ini relasi antar tabel menggunakan table designer yang terdapat pada pada phpmyadmin sebagai perangkat lunak administrasi database. Relasi antar tabel menggunakan tabel designer dapat dilihat pada gambar 5 . 
JURNAL MEDIA INFORMATIKA BUDIDARMA

Volume 4, Nomor 2, April 2020, Page 347-354

ISSN 2614-5278 (media cetak), ISSN 2548-8368 (media online)

Available Online at https://ejurnal.stmik-budidarma.ac.id/index.php/mib DOI 10.30865/mib.v4i2.2061

Development, tahap dimana model konseptual yang telah dirancang mulai di bangun menggunakan bahasa pemrograman. Dalam konsep Rapid Application Development, tahap ini merupakan tahap dimana membuat protipe lambat (late prototype) yang sudah menggunakan app builder dan semacamnya.

Digital signage dibangun menggunakan bahasa pemrograman PHP, HTML, CSS dan Javascript, sedangkan aplikasi chatbot menggunakan bahasa python yang dihubungkan ke API dari telegram sebagai media pengelolaan pola (pattern) dan respon dari dan kepada penerima pesan.

Untuk penyimpanan data, baik digital signage maupun aplikasi chatbot menggunakan MySql sebagai sumber database bersama. Tampilan dari papan informasi digital dapat dilihat pada gambar 6 .

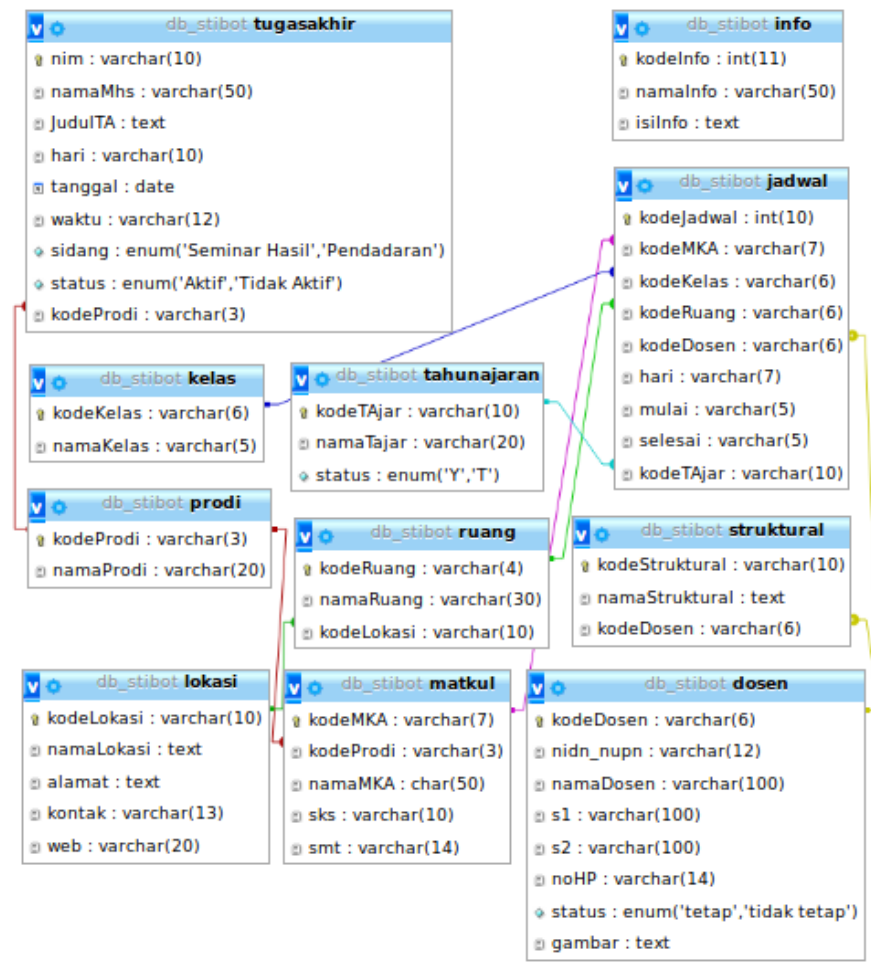

Gambar 5. Relasi Antar Tabel Menggunakan Tabel Designer

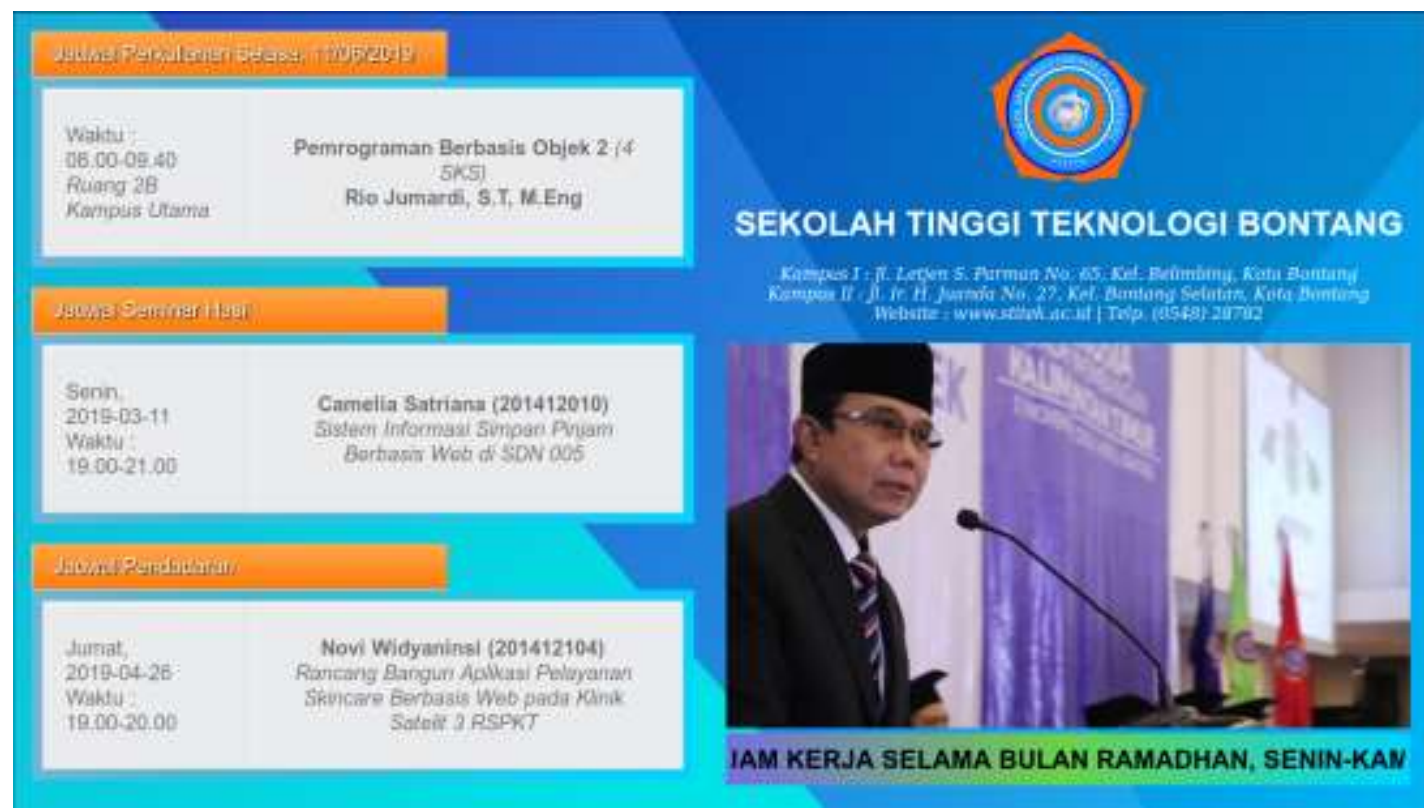

Gambar 6. Tampilan Digital signage

Informasi yang ditampilkan pada digital signage berupa informasi jadwal perkuliahan, informasi jadwal seminar hasil, jadwal pendadaran, informasi berupa video atau gambar serta informasi lain dalam kemasan pengumuman.

Untuk melengkapi pemenuhan kebutuhan informasi kepada mahasiswa juga dibuat chatbot telegram yang berisi informasi seperti pada digital signage dengan dilengkapi informasi lainnya seperti informasi dosen, 


\section{JURNAL MEDIA INFORMATIKA BUDIDARMA}

Volume 4, Nomor 2, April 2020, Page 347-354

ISSN 2614-5278 (media cetak), ISSN 2548-8368 (media online)

Available Online at https://ejurnal.stmik-budidarma.ac.id/index.php/mib DOI 10.30865/mib.v4i2.2061

struktural atau pejabat kampus serta informasi lokasi kampus sesuai dengan permintaan informasi yang dilakukan mahasiswa melalui telegram messenger.

Chatbot merupakan program komputer yang melakukan dialog interaktif berbasis tekstual. Chatbot dalam penelitian ini menggunakan sistem sederhana dengan cara memindai kata kunci inputan. Kemudian bot akan mencari data yang paling sesuai dan memberikan balasan sesuai dengan kata yang paling cocok dari permintaan data tersebut. Data balasan yang diberikan merupakan data yang telah disimpan pada database. Kata kunci yang terdapat pada chatbot ini didaftarkan menggunakan bahasa pemrograman python. Beberapa kata kunci yang terdaftar pada chatbot ini diantaranya, jadwal, jadwal kuliah, jadwal tugas akhir, dosen, lokasi serta struktural. Tampilan dari Chatbot dapat dilihat pada Gambar 7, 8, 9 dan 10.

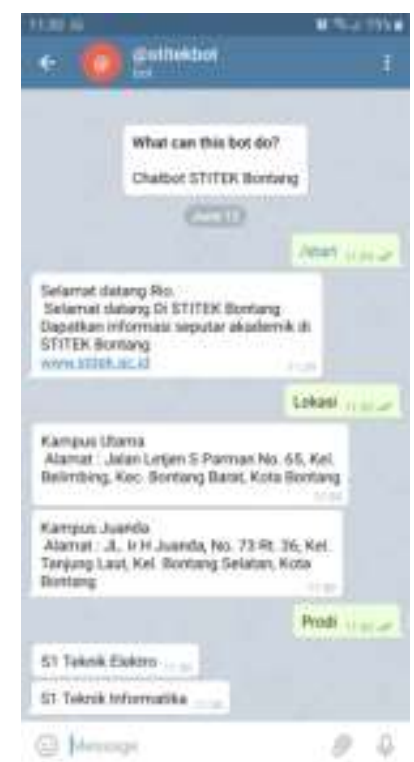

Gambar 7. Chatbot Informasi Awal dan Informasi Lokasi.

Informasi yang ditampilkan pada saat pertama kali membuka chatbot adalah informasi pengantar berkaitan dengan aplikasi. Kemudian pengguna menulis kata kunci sesuai dengan informasi yang diinginkan. Pada Gambar 7 pengguna memasukkan kata kunci lokasi dan prodi sehingga chatbot akan memberikan response berupa informasi lokasi kampus dan informasi berkaitan dengan program studi.

Kata kunci lain yang digunakan adalah info dosen untuk mengetahui informasi dosen. Informasi dosen berupa nama lengkap beserta gelar dosen dan nomor induk dosen nasional (NIDN). Infromasi lainnya dapat berupa jabatan structural yang diduduki dosen. Tampilan informasi dosen dapat dilihat pada Gambar 8 .

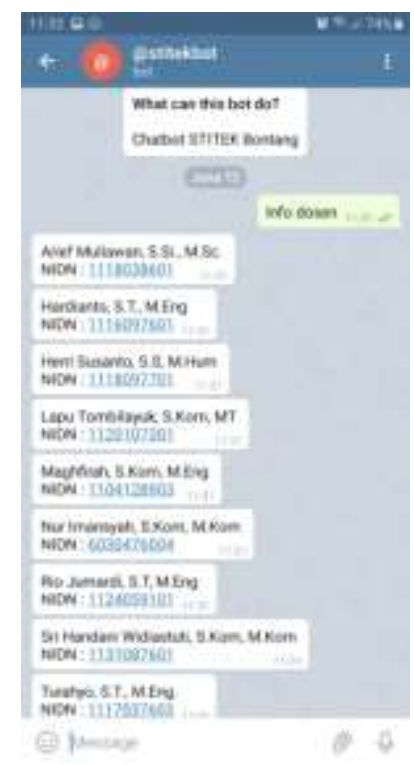

Gambar 8. Chatbot Informasi Data Dosen

Kata kunci jadwal seminar hasil dan jadwal pendadran merupakan kata kunci yang digunakan untuk pemerolehan informasi penjadwalan seminar hasil dan pendadaran tugas akhir. Informasi yang diberikan berupa 
JURNAL MEDIA INFORMATIKA BUDIDARMA

Volume 4, Nomor 2, April 2020, Page 347-354

ISSN 2614-5278 (media cetak), ISSN 2548-8368 (media online)

Available Online at https://ejurnal.stmik-budidarma.ac.id/index.php/mib DOI 10.30865/mib.v4i2.2061

nama peserta siding, hari dan tanggal pelaksanaan beserta judul tugas akhir yang kerjakan. Tampilan informasi jadwal seminar hasil dan pendadaran tugas akhir dapat dilihat pada Gambar 9.

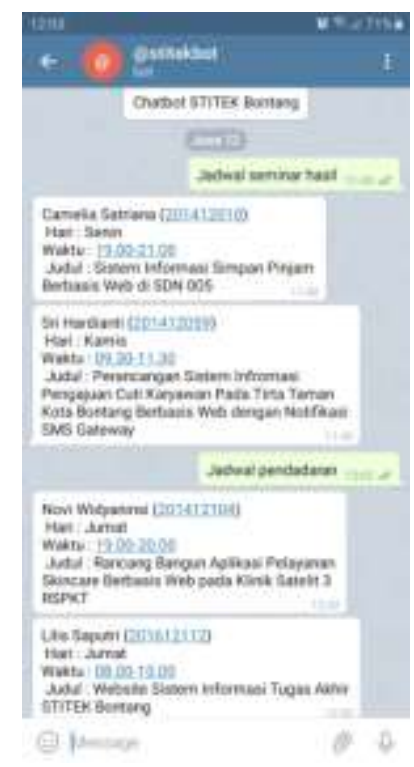

Gambar 9. Chatbot Informasi Jadwal Tugas Akhir

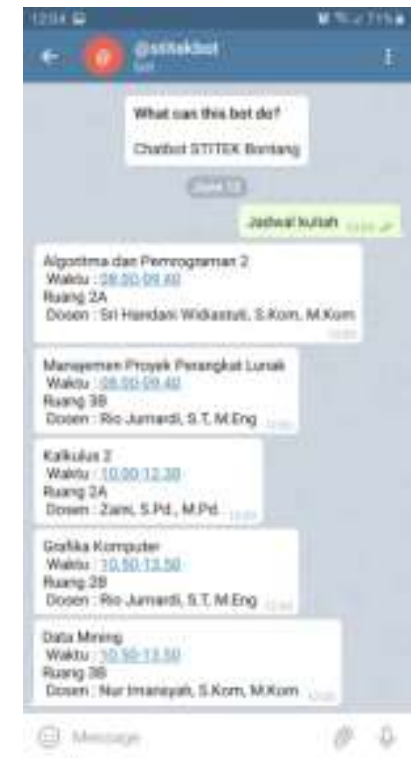

Gambar 10. Chatbot Informasi Jadwal Perkuliahan

Gambar 10 menunjukkan informasi jadwal perkuliahan yang diperoleh ketika pengguna memasukkan kata kunci jadwal kuliah. Informasi jadwal perkuliahan berupa informasi harian perkuliahan yang terdiri dari nama mata kuliah, waktu pengajaran, ruang perkuliahan dan dosen pengampu mata kuliah.

\section{KESIMPULAN}

Kesimpulan dari penelitian ini adalah papan digital berbasis digital atau digital signage dapat mengganti papan informasi berbahan konvensional seperti kayu atau besi dengan memberikan informasi yang akurat, relevan, tepat waktu dan bekerja secara dinamis. Chatbot messenger dapat membantu memberikan informasi akademik kepada mahasiswa secara dua arah dengan konsep request-response dari dan kepada mahasiswa melalui media telegram messenger. Kolaborasi antara digital signage dan chatbot messenger dapat membantu mahasiswa dalam pemenuhan informasi terkait akademik secara efektif dan efisien. 
JURNAL MEDIA INFORMATIKA BUDIDARMA

Volume 4, Nomor 2, April 2020, Page 347-354

ISSN 2614-5278 (media cetak), ISSN 2548-8368 (media online)

Available Online at https://ejurnal.stmik-budidarma.ac.id/index.php/mib

DOI 10.30865/mib.v4i2.2061

\section{UCAPAN TERIMAKASIH}

Penulis ucapkan terima kasih kepada semua pihak yang telah membantu penulis dalam menyelasaikan penelitian ini khususnya kepada Sekolah Tinggi Teknologi Bontang dan STMIK Asia Malang atas kolaborasi dan kerjasamanya dalam penelitian ini.

\section{REFERENCES}

[1] S. Y. Lestari, N. Komariah, and E. Rizal, "Pengelolaan Informasi Sebagai Upaya Memenuhi Kebutuhan Informasi Masyarakat," J. Kaji. Inf. dan Perpust., vol. 4, no. 1, p. 59, 2016, doi: 10.24198/jkip.v4i1.8499.

[2] R. N. D and R. M. N. Halim, "Perancangan Papan Informasi Digital untuk Kehadiran Dosen pada STIPER Sriwigama Palembang," 2018, pp. 128-136.

[3] P. Anggraeni and P. N. Madiawati, "The Efect Of Trust and Information Quality to Online Purchase Decision on The Site www.traveloka.com Penia," in Proceeding of Management, 2016, vol. 3, no. 2, pp. 1880-1887.

[4] T. Sutabri, Konsep Sistem Informasi. Yogyakarta: Andi, 2012.

[5] A. S. Putra and O. M. Febriani, "Knowledge Management Online Application in PDAM Lampung Province," in Prosiding International conference on Information Technology and Business (ICITB), 2018, no. 1, pp. 181-187.

[6] M. I. Zakariya and R. Cahyana, "Pengembangan Papan Informasi Digital,” J. Algoritm., vol. 13, no. 1, pp. 2302-7339, 2016.

[7] R. Cahyana, "The Service Candidate Modelling of Academic Information Channel by Appliying of Service OrientedArchitecture," Int. J. Basic Appl. Sci., vol. 3, no. 1, pp. 82-87, 2014.

[8] A. Mulyana and M. Aria, "Perancangan Digital Signage Sebagai Papan Informasi Digital," Maj. Ilm. UNIKOM, vol. 13, no. 2, pp. 111-118, 2015, doi: 10.34010/miu.v13i2.118.

[9] I. N. S. Paliwahet, I. M. Sukarsa, and I. K. Gede Darma Putra, "Pencarian Informasi Wisata Daerah Bali Menggunakan Teknologi Chatbot," Lontar Komput. J. Ilm. Teknol. Inf., vol. 8, no. 3, p. 144, 2018, doi: 10.24843/lkjiti.2017.v08.i03.p01.

[10] E. N. S. C. P and I. Afrianto, "Rancang Bangun Aplikasi Chatbot Informasi Objek Wisata Kota Bandung Dengan Pendekatan Natural Languange Processing," J. Ilm. Komput. dan Inform., vol. 4, no. 1, pp. 49-54, 2015.

[11] S. Silestian, S. Sumitro, and I. Purnama, "Penerapan Formulir KTP Berbasis Android: Studi Pada Kantor Camat Rantau Utara Kabupaten Labuhanbatu," J. Media Inform. Budidarma, vol. 2, no. 4, p. 150, 2018, doi: 10.30865/mib.v2i4.838.

[12] A. Yuliawan, N. Sakti, Y. Priyandari, and M. Hisjam, "Perancangan Sistem Informasi Manajemen Auditor Teknologi pada Sistem Nasional Audit Teknologi ( SNAT ) Menggunakan Metode Grapple," in Seminar Internasional dan Konferensi Nasional IDEC 2016, 2016, pp. 364-373.

[13] H. Sofyan, F. R. Kodong, and M. F. Zulpi, “Aplikasi Berbasis Android Pemilihan Metode Penanggulangan Well Kick," in Seminar Nasional Informatika 2014, 2014, pp. 214-223. 